Article

\title{
Evaluation of the Use of Energy in the Production of Sweet Sorghum (Sorghum Bicolor (L.) Moench) under Different Production Systems
}

\author{
Iosvany López-Sandin ${ }^{1,2}$, Guadalupe Gutiérrez-Soto ${ }^{1}$, Adriana Gutiérrez-Díez ${ }^{1}$, \\ Nancy Medina-Herrera ${ }^{1}$, Edgar Gutiérrez-Castorena ${ }^{1} \mathbb{D}$ and Francisco Zavala-García ${ }^{1, *}$ \\ 1 Facultad de Agronomía, Universidad Autónoma de Nuevo León, \\ Francisco Villa S/N Col. Ex Hacienda El Canadá, 66415 General Escobedo, N.L., Mexico; \\ iosvanyls@gmail.com (I.L.-S.); ggutierrez0402@gmail.com (G.G.-S.); \\ adriana.gutierrezdz@uanl.edu.mx (A.G.-D.); nantelucas@gmail.com (N.M.-H.); \\ vladimir@colpos.mx (E.G.-C.) \\ 2 Departamento de Mecánica Aplicada, Facultad de Ciencias Técnicas, Universidad de Ciego de Ávila, \\ Carretera a Morón, Km 9 1/2, 69450 Ciego de Ávila, Cuba \\ * Correspondence: francisco.zavalag@uanl.mx; Tel.: +52-8112-7740-14
}

Received: 26 March 2019; Accepted: 22 April 2019; Published: 6 May 2019

\begin{abstract}
The growing global demand for energy and the reduction of energy based on oil are driving the search for new sources of energy that are environmentally friendly. To achieve this goal, it is also necessary to optimize the related processes. In this study, the behavior of the agronomic parameters of, and the energy invested in, production systems based on a new variety of sweet sorghum (Sorghum bicolor (L.) Moench) called ROGER were determined to define the optimal production conditions. To this end, three methods of tillage (minimum, traditional, and traditional tillage with rupture of the plow layer) and three types of fertilizers (inorganic, organic, and without fertilizer) were established, and to estimate the energy efficiency, the inputs and the energy outputs of each system were considered. The traditional tillage with breaking of the plow layer and the organic fertilizer showed the highest values of plant height ( 2.45 and $2.39 \mathrm{~m}$, respectively); total fresh weight of the plant (51.66 and $50.77 \mathrm{t} \cdot \mathrm{ha}^{-1}$, respectively), of the stem (42.7 and $41.05 \mathrm{t} \cdot \mathrm{ha} \mathrm{a}^{-1}$, respectively), and of the juice (21.89 and $22.57 \mathrm{t} \cdot \mathrm{ha}^{-1}$, respectively); the volume of the juice (20,783.12 and 22,529.59 L.ha ${ }^{-1}$, respectively); and Brix degrees (16.04\% and $15.01 \%$, respectively). However, the highest energy efficiency was registered in the production system that used the minimum tillage, with a value of 15.11, as well as when no fertilizer was applied with 18.68 .
\end{abstract}

Keywords: energy efficiency; fertilization; tillage; agronomic parameters; ROGER variety

\section{Introduction}

Energy demand has increased over the years due to factors such as the growing population size, the expansion of large cities, increased living standards, increased global pollution, the reduction of natural resources and productive areas, as well as the extinction of plant and animal species. The negative effects associated with increased energy production may be mitigated if renewable energy sources are employed and increased efficiency of the related production processes is attained, so that energy consumption decreases without affecting quality of life [1,2]. Energy balances permit evaluation and comparison of the efficiency of production methods of alternative energy [3]. Energy efficiency favors sustainable agriculture [4] and accounts for energy inputs and outputs of the production system (Figure 1, first stage); however, energy uses and production differ widely among crops, production systems, and management intensities. As such, the efficiency of a production process is measured 
by the relationship between the benefits obtained and the resources used. Therefore, it is important to select the correct analysis method and the right tools. However, in many cases, this depends on efficiently taking advantage of the available (conventional) resources without affecting the efficiency and quality of the process [5]. Management practices have considerable effects on the contribution and energy efficiency of crop production systems [6]; thus, energy demand in agriculture is classified according to the energy inputs of each production system $[7,8]$. An efficient process requires that the energy invested in the production of a biofuel unit, including its agricultural and industrial stages, be less than the energy that leaves the system [9].

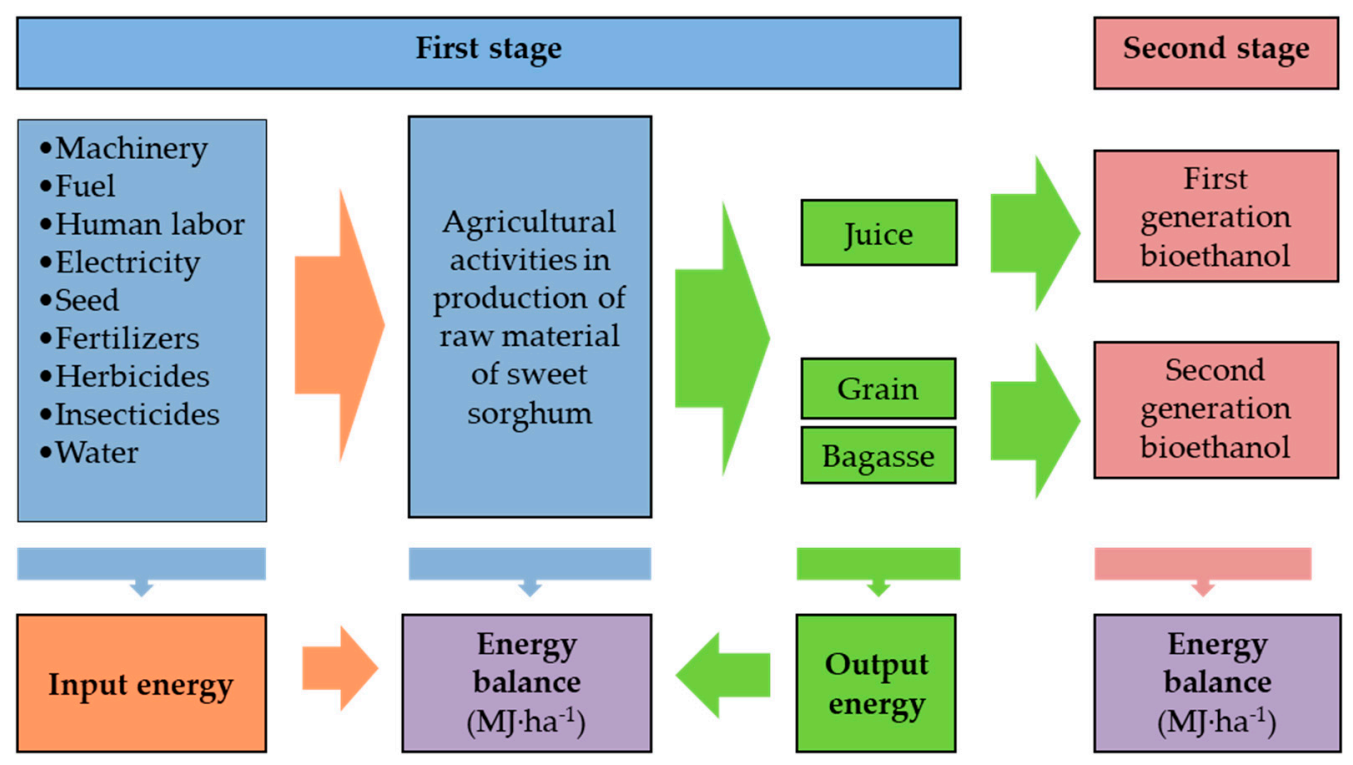

Figure 1. Block diagram of the production of raw materials of sweet sorghum (Sorghum bicolor (L.) Moench) (first stage) and its respective energy inputs and outputs from the system.

Biofuels usually derive from vegetable or animal biomass and provide a viable source of energy. Several studies have shown that plants grown for these purposes might reduce net emissions of greenhouse gases [10]. According to Bai et al. [11], the most common biomass for fuel production includes corn, wheat, sugarcane, sugar beet, and sweet sorghum (Sorghum bicolor (L.) Moench). These sources have shown great potential as substitutes for conventional fuels and for reducing polluting emissions. In addition, sweet sorghum has shown great adaptability and is resistant to drought, high temperatures, and salinity. Its characteristics make it an ideal raw material for the sustainable production of biofuels with Brix degrees of 13-24\%, sucrose in juice of $7.2-15.5 \%$, total

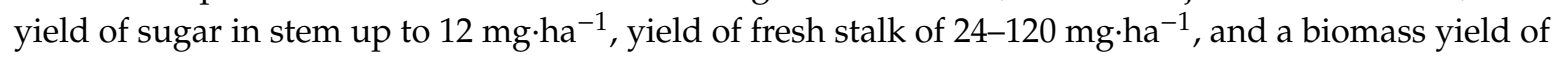
36-140 th ha ${ }^{-1}$ [12-14]. However, yields vary according to variety, cultivation conditions (soil, water, climate, pests, and diseases), inputs, and agronomic practices [15]. In comparison with other crops, it has a lower use of inputs due to the favorable combination of its agronomic and technological characteristics, making it one of the best raw materials in the production of sugar and biofuels [16-18]. Due to the high capacity of the outbreak, several harvests can be made of the same plant, which reduces the cost of labor, the time of preparation of the soil and planting, the use of seeds, and energy [19]. It is also good for producing more ethanol per unit area than other crops, requiring fewer chemical reactions and less energy to obtain it from the juice, with a minimum cost of cultivation, which can be three times less than that of sugarcane. These characteristics make sorghum a suitable crop for the production of bioethanol. Its biomass production with a limited water supply separates it from other crops [20]. Based on the above mentioned points, this research determined the agronomic parameters and energy consumed in different production systems of a new variety sweet sorghum. 


\section{Materials and Methods}

\subsection{Site Description}

Research was conducted at the Marín Academic Unit of the Agronomy School at Nuevo Leon Autonomous University (FAUANL). This school is located at km 17 of the Zuazua-Marín Highway in the municipality of Marín, Nuevo León, México. Geographically, it is located at coordinates $25^{\circ} 53^{\prime} \mathrm{N}$, $100^{\circ} 2^{\prime} \mathrm{W}$, at $355 \mathrm{~m}$ above sea level. The climate corresponds to a BS1 (h) w (e), and it is described as a dry warm steppe with rainfall in summer. Annual rainfall ranges between 250 and $500 \mathrm{~mm}$, and the average annual temperature is $22^{\circ} \mathrm{C}$. The soil type is thin, compacted vertisol with a high content of clay and calcium carbonate, a low organic matter content, and pH between 7.5 and 8.5.

\subsection{Plant Material}

The ROGER sweet sorghum variety (of open pollination, photosensitive and with high content of juice and sugars in their stems), a genotype registered with the Mexican Agriculture Secretariat in the Catalog of Plant Varieties under the code SOG-261-050315, was used. This genotype has approximately 75 days to flowering, a plant height of $2.4 \mathrm{~m}$, an average yield of $45 \mathrm{t} \cdot \mathrm{ha}^{-1}$ of fresh weight, and a crop cycle of 130 days.

\subsection{Establishment and Experimental Design}

For data collection, a randomized complete-block design was used with arrangements in divided plots and three repetitions. Experimental treatments were established from three tillage methods and three types of fertilization. The tillage methods corresponded to the main plots, and fertilization systems were distributed within each main plot at subplots. Each experimental unit was $6.4 \times 40 \mathrm{~m}$. Treatments were: L1-minimum tillage (clearing and harrowing); L2-traditional work (clearing, plowing, and harrowing); L3 - traditional plowing with breaking of the plow layer (clearing, subsoil, plowing, and harrowing); F1-organic fertilization; F2-inorganic fertilization; and F3-without fertilization. In total, there were nine treatments from the combination of the mentioned factors.

\subsection{Agronomic Parameters}

The following agronomic parameters were measured: (1) Days to flowering (DF), when 50\% of the plants were in bloom; and (2) plant height (PH), from the ground to the apex of the panicle. From a sample of 200 plants per treatment, the following variables were estimated: (3) total fresh plant weight (TPW), measured as the weight of the entire plant from 200 plants in $\mathrm{kg}$; (4) stem weight (SW), for which the 200 stems were weighed without leaves and panicles; (5) leaf weight (LW), measured as the weight of fresh leaves; (6) spike weight (SW), measured only as the weight of the spike, including grain; (7) juice weight (JW), after extraction from the 200 stems, juice was collected and weighted; (8) juice volume (JV), with a graduated cylinder, the volume of the juice obtained from the 200 stems was measured; (9) degrees Brix $\left({ }^{\circ} \mathrm{B}\right)$, measured using a manual digital refractometer (PAL 1) from a juice sample; and (10) total dry plant weight (DPW), obtained by drying a sample of 10 plants from the 200 harvested from each experimental unit in an oven (HAFO 1600) at $65{ }^{\circ} \mathrm{C}$ until reaching constant weight.

\subsection{Agricultural Labor}

Soil preparation started three months before sowing with clearing. After 21 days, when the soil was dry and in decomposition, subsoil labor was carried out according to the treatments, introducing the chisel $0.75 \mathrm{~m}$ into the ground and breaking compact and deep layers of the soil. After a 45-day rest period, plowing and harrowing labors were carried out, both with disk implements at a depth of 0.29 and $0.23 \mathrm{~m}$, respectively. Subsequently, crossing and recrossing with disc harrow was performed. Planting was carried out on 5 March 2018 (winter-spring cycle of 2018-2019), with a depth of $0.05 \mathrm{~m}$, 
at a distance between rows of $0.8 \mathrm{~m}$ and between plants of $0.07 \mathrm{~m}$, for a density of 178,500 plants ha ${ }^{-1}$. A superficial drip irrigation system was used.

Organic fertilizer was applied 20 days before sowing, with a dose of 3 ton.ha ${ }^{-1}$ of chicken manure (N: $60 \mathrm{Kg} \cdot \mathrm{ha}^{-1}$, P: $65 \mathrm{Kg} \cdot \mathrm{ha}^{-1}$, and K: $\left.75 \mathrm{Kg} \cdot \mathrm{ha}^{-1}\right)$. Chemical fertilizer was applied at sowing (N: $50 \mathrm{Kg} \cdot \mathrm{ha}^{-1}$ and P: $25 \mathrm{Kg} \cdot \mathrm{ha}^{-1}$ ) and 25 days after (N: $50 \mathrm{Kg} \cdot \mathrm{ha}^{-1}$ and P: $25 \mathrm{Kg} \cdot \mathrm{ha}^{-1}$ ). Pest and weed control were performed by application of pesticides and herbicides, respectively. For the cogollero worm (Spodoptera frugiperda), a dose of $0.6 \mathrm{~L} \cdot \mathrm{ha}^{-1}$ of Pounce $340 \mathrm{CE}^{\circledR}$ was applied on days 28 and 59 after sowing. For the yellow aphid, $0.3 \mathrm{~L} \cdot \mathrm{ha}^{-1}$ of Murralla ${ }^{\circledR}$ was applied on days 32 and 81 after sowing. For the weeds, $1 \mathrm{~L} \cdot \mathrm{ha}^{-1}$ of Fito Amina $40^{\circledR}$ was applied on days 35 and 64 after sowing.

Sorghum was harvested at the end of stage seven (milky grain), as described by Vanderlip [21], approximately 19 weeks after planting. In this stage, sorghum stems reach the maximum sugar concentration [22]. Plants were harvested manually at a cutting height of $0.03-0.04 \mathrm{~m}$ from the base of the stem.

\subsection{Energy Balance}

\subsubsection{Energy in Mechanized Agricultural Labor}

Energy consumption from mechanized agricultural labor was estimated using the methodology described by de las Cuevas et al. [23] and Paneque and Sánchez [24], based on proposals by Bridges and Smith [25] and supported by the background research of Stout [26]. This methodology determines the energy cost in $\mathrm{MJ} \cdot \mathrm{h}^{-1}$ by adding the energy required in construction materials, manufacturing and transportation, fuel, lubricants/filters, maintenance/repair, labor, fertilizers, pesticides, and seeds. For this purpose, the energy equivalents shown in Table 1 were used.

Table 1. Energy equivalents.

\begin{tabular}{cccc}
\hline Concept & Unit & Equivalent Energy (MJ. unit $^{-\mathbf{1}}$ ) & Source \\
\hline Human Labor Manual & $\mathrm{h}$ & 1.95 & {$[27]$} \\
Machinery & $\mathrm{kg}$ & 1.05 & {$[28]$} \\
Diesel & $\mathrm{L}$ & $138^{*}$ & {$[27]$} \\
Nitrogen & $\mathrm{kg}$ & 47.8 & {$[29]$} \\
Phosphorus & $\mathrm{kg}$ & 77.5 & {$[30]$} \\
Potassium & $\mathrm{kg}$ & 12.44 & {$[31]$} \\
Insecticide & $\mathrm{kg}$ & 11.15 & {$[31]$} \\
Herbicide & $\mathrm{kg}$ & 278 & {$[32]$} \\
Poultry Manure & $\mathrm{kg}$ & 214 & {$[32]$} \\
Seed & $\mathrm{kg}$ & 0.3 & {$[28]$} \\
Irrigation Water & $\mathrm{m}$ & 59.50 & {$[33]$} \\
Electricity & $\mathrm{kW} \cdot \mathrm{h}^{3}$ & 1.02 & {$[34]$} \\
Transportation & $\mathrm{MJ} \cdot \mathrm{km}^{-1} \cdot \mathrm{t}^{-1}$ & 11.93 & {$[35]$} \\
\end{tabular}

* Includes the energy cost in steel production plus $50 \%$ for assembly.

Total energy expenditure in mechanized agricultural activity $\left(\mathrm{MJ} \cdot \mathrm{h}^{-1}\right)$ was determined by the following equation:

$$
E S T=E S M+E S F+E S L+E S R+E S I+E S H+E S E
$$

where ESM is the energy invested in materials, manufacture, and transport $\left(\mathrm{MJ} \cdot \mathrm{h}^{-1}\right)$; ESF is the energy invested in fuel $\left(\mathrm{MJ} \cdot \mathrm{h}^{-1}\right)$; ESL is the energy invested in lubricants/filters $\left(\mathrm{MJ} \cdot \mathrm{h}^{-1}\right)$; ESR is the energy invested in maintenance and repair $\left(\mathrm{MJ} \cdot \mathrm{h}^{-1}\right)$; ESI is the energy invested in seeds, fertilizers, herbicides, and pesticides $\left(\mathrm{MJ} \cdot \mathrm{h}^{-1}\right)$; ESH is the energy invested in human labor $\left(\mathrm{MJ} \cdot \mathrm{h}^{-1}\right)$; and ESE is the energy invested in electricity $\left(\mathrm{MJ} \cdot \mathrm{h}^{-1}\right)$ [35]. The energy invested in lubricants/filters as well as maintenance 
and repairs (ESR) was estimated according to Fluck [36] and Paneque et al. [37] as 5\% and 129\% of the energy required in fuel (ESF) and in materials, manufacturing and transport (ESM), respectively.

The energy invested in materials, manufacturing, and transportation was determined by the following equation:

$$
E S M=\frac{W t * E U t}{L U t}+\frac{W m * E U m}{L U m}
$$

where $W t$ is the weight of the tractor $(\mathrm{kg}), W m$ is the weight of the agricultural machinery $(\mathrm{kg}), E U t$ is the energy per unit mass of the tractor $\left(\mathrm{MJ} \cdot \mathrm{kg}^{-1}\right), E U m$ is the energy per unit mass of the agricultural machinery (MJ. $\mathrm{kg}^{-1}$ ) [19], VUt is the useful life of the tractor (h), and VUm is the useful life of the agricultural machinery (h). Values for $W t, W m, L U t$, and $L U m$ were taken from technical specifications in the manufacturer's catalog.

The energy corresponding to fuel was determined by the following equation:

$$
E S F=\sum_{l=1}^{l=0} C h * E q f
$$

where $C h$ is the hourly fuel consumption $\left(L \cdot h^{-1}\right)$, or the difference of the initial volume minus the final volume in the tractor fuel tank (L), divided by the operating time (h), and Eqf is the fuel equivalent energy $\left(\mathrm{MJ} \cdot \mathrm{L}^{-1}\right)$ [29].

The energy corresponding to seeds, fertilizers, herbicides, and pesticides was determined by the following equation:

$$
E S I N=\sum_{n=1}^{n=s} N s e * \text { Eqse }+\sum_{n=1}^{n=s} \text { Fer } * \text { Eqfer }+\sum_{n=1}^{n=s} \text { Her } * \text { Eqher }+\sum_{n=1}^{n=s} \text { Pes } * \text { Eqpes }
$$

where Nse is the quantity of seeds planted $\left(\mathrm{kg} \cdot \mathrm{ha}^{-1}\right)$, Eqse is the equivalent energy for seed production $\left(\mathrm{MJ} \cdot \mathrm{kg}^{-1}\right)$ [33], Fer is the amount of fertilizer applied $\left(\mathrm{kg} \cdot \mathrm{ha}^{-1}\right)$, Eqfer is the equivalent energy in the production of fertilizer (MJ.kg ${ }^{-1}$ ) [30,31], Her is the applied dose of herbicide $\left(\mathrm{L} \cdot \mathrm{ha}{ }^{-1}\right)$, Eqher is the equivalent energy for production of the herbicide (MJ. $\left.\mathrm{L}^{-1}\right)$ [23], Pes is the applied dose of pesticides $\left(\mathrm{L} \cdot \mathrm{ha}^{-1}\right)$, and Eqpes is the equivalent energy in the production of pesticides (MJ. $\left.\mathrm{L}^{-1}\right)$ [32].

The energy sequestered per hectare $\left(\mathrm{MJ} \cdot \mathrm{ha}^{-1}\right.$ ) was determined by the following equation:

$$
E S h a=\frac{E S T}{W p}
$$

where $W p$ is the hourly performance in the mechanized agricultural operation $\left(\mathrm{ha} \cdot \mathrm{h}^{-1}\right)$.

\subsubsection{Energy Indexes}

The energy indexes were determined according to Tabatabaie et al. [38] and Nabavi et al. [39] as follows:

Energy efficiency (EE) is the energy provided by the resulting product(s) from the production process (OE) compared to the energy required to obtain it (IE). It is mainly used when said process is for the generation of energy (Equation (6)):

$$
\text { Energy efficiency }=\frac{\text { Output energy }\left(M J \cdot h a^{-1}\right)}{\text { Input energy }\left(M J \cdot h a^{-1}\right)} .
$$

Energy productivity (EP) is the ratio between the amount of product(s) measured in mass units and the energy required to obtain it (Equation (7)): 


$$
\text { Energy productivy }=\frac{\text { Sorghum yield }\left(\mathrm{kg} \cdot h \mathrm{~h}^{-1}\right)}{\text { Input energy }\left(M J \cdot h a^{-1}\right)}
$$

Specific energy (SE) is the relationship between the energy provided by the resulting product(s) of the productive process and the quantity of product(s) measured in units of mass (Equation (8)):

$$
\text { Specific energy }=\frac{\text { Output energy }\left(M J h a^{-1}\right)}{\text { Sorghum yield }\left(k g h a^{-1}\right)} .
$$

Net energy (NE) is the difference between the energy provided by the product(s) from the production process and the energy required to obtain it (Equation (9)):

$$
\text { Net energy }=\text { Output energy }\left(M J a^{-1}\right)-\operatorname{Input~energy~}\left(M J h a^{-1}\right) \text {. }
$$

The calorific value of the dry sorghum biomass (spike, leaf, and stem) was determined using a Parr calorimeter bomb following the methodology described in the Official Mexican Norm "Determination of the Calorific Power in Solid Waste" DGN-AA-33-1976. Measurements were conducted in the laboratory of Nutrition and Food Quality of the Faculty of Agronomy, Autonomous University of Nuevo Leon.

\subsection{Statistical Analysis}

The effects of the different production systems on the productivity and the agronomic characteristics of the crop were determined through a randomized complete-block analysis in a split-plot arrangement using the statistical package SPSS Statistics. Subsequently, the mean comparison test was applied by the Tukey method with a probability of $5 \%$.

\section{Results and Discussion}

\subsection{Agronomic Parameters}

Analysis of variance of the agronomic parameters in the ROGER variety is shown in Table 2. It was possible to observe significant statistical differences $(p \leq 0.05)$ and highly significant differences $(p<0.01)$ but without interaction for tillage $\times$ fertilization. Comparison of means (Table 3$)$ showed that among tillage treatments, L3 had the highest values $(p \leq 0.05)$ for PH $(2.45 \mathrm{~m})$, TPW $\left(51.66 \mathrm{t} \cdot \mathrm{ha}^{-1}\right)$,

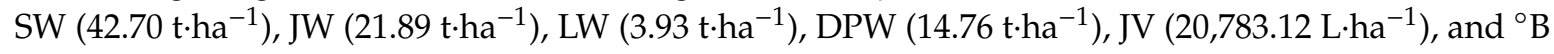
(16.04\%); but for all variables with the exception of LW, it was statistically equal to L2. However, no treatment presented a significant difference $(p \geq 0.05)$ in DF and SW. These results may have been due to the greater depth in the tillage treatment, which allowed rupture of the plow layer and, thus, higher root development and increased nutrient availability [6,40]. This setup might contribute to increased infiltration that takes better advantage of the rainwater and controls some dormant structures from fungi and weed seeds.

Regarding types of fertilization, F1 had the highest values for PH (2.39 m), TPW (50.77 tha $\left.{ }^{-1}\right)$, SW (41.05 th.ha $\left.{ }^{-1}\right)$, JW (22.57 thha $\left.{ }^{-1}\right)$, LW (3.86 thha $\left.{ }^{-1}\right)$, SW (5.86 thha $\left.{ }^{-1}\right)$, and JV (22,529.59 L·ha $\left.{ }^{-1}\right)$, while DF, DPW, and ${ }^{\circ} \mathrm{B}$ were not different among treatments $(p \geq 0.05)$. It is worth mentioning that for the variables mentioned, F1 was statistically equal to F2.

In general, PH values obtained were higher than those reported by Oyier et al. [41] for the EUSS10 genotype $(1.88 \mathrm{~m})$. There is great heterogeneity in plant size from different genotypes and varieties of sweet sorghum. Depending on the conditions of the production system and the genotype, height varies from 2 to $3 \mathrm{~m}$ [42]. It should be noted that sweet varieties are higher than grain producers [43] and are of great technological interest in the production of biomass and bioenergy [42]. Results for TPW, SW, and DPW reported here are similar to values from other sweet sorghum varieties for bioethanol production (from 35 to $52.12 \mathrm{t} \cdot \mathrm{ha}^{-1}$ ) [44]. 
Table 2. Mean squares for the analysis of variance for agronomic parameters.

\begin{tabular}{|c|c|c|c|c|c|c|c|c|c|c|c|}
\hline \multirow{2}{*}{ S.V. } & \multirow{2}{*}{ D.F. } & \multicolumn{10}{|c|}{ MS } \\
\hline & & DF & PH & TPW & SW & LW & SW & JW & JV & ${ }^{\circ} \mathbf{B}$ & DPW \\
\hline Repetition & 2 & 17.37 & 0.01 & 30.14 & 18.01 & 0.14 & 1.20 & 1.67 & $9.71 \times 10^{6}$ & 6.17 & 44.25 \\
\hline Tillage & 2 & $22.48^{\mathrm{ns}}$ & $0.07^{* *}$ & $158.02 *$ & 141.11 * & $1.37^{* *}$ & $0.43^{\mathrm{ns}}$ & $36.70 *$ & $2.83 \times 10^{7} *$ & $9.80 *$ & $45.66^{*}$ \\
\hline Error (a) & 4 & 4.04 & 0.0019 & 13.63 & 11.07 & 0.07 & 0.69 & 14.39 & $6.85 \times 10^{6}$ & 0.98 & 10.26 \\
\hline Fertilization & 2 & $23.59^{\mathrm{ns}}$ & $0.01 *$ & $71.96^{*}$ & $33.58 *$ & $0.66^{*}$ & $3.86^{*}$ & $51.15^{*}$ & $8.74 \times 10^{7 *}$ & $2.01^{\mathrm{ns}}$ & $14.77^{\mathrm{ns}}$ \\
\hline Tillage $\times$ Fertilization & 4 & $1.93^{\mathrm{ns}}$ & $0.002^{\mathrm{ns}}$ & $4.75^{\mathrm{ns}}$ & $3.47^{\mathrm{ns}}$ & $0.04^{\mathrm{ns}}$ & $0.61^{\mathrm{ns}}$ & $9.37^{\mathrm{ns}}$ & $7.48 \times 10^{6 \mathrm{~ns}}$ & $0.96^{\mathrm{ns}}$ & $14.31^{\mathrm{ns}}$ \\
\hline Error (b) & 12 & 11.43 & 0.0012 & 14.50 & 8.32 & 0.10 & 0.86 & 3.94 & $6.01 \times 10^{6}$ & 1.06 & 10.67 \\
\hline C.V. $(\%)$ & & 4.56 & 1.48 & 7.96 & 7.41 & 8.68 & 17.55 & & 9.84 & 12.76 & 6.91 \\
\hline
\end{tabular}

Table 3. Agronomic behavior of sweet sorghum according to tillage (L) and fertilization (F).

\begin{tabular}{|c|c|c|c|c|c|c|c|c|c|c|}
\hline \multirow{2}{*}{$\mathbf{T x}$} & \multirow{2}{*}{ DF } & \multirow{2}{*}{ PH (m) } & TPW & SW & JW & LW & SW & DPW & \multirow{2}{*}{$\underset{\left(L \cdot h a^{-1}\right)}{J V}$} & \multirow{2}{*}{$\begin{array}{l}{ }^{\circ} \mathrm{B} \\
(\%)\end{array}$} \\
\hline & & & & & $\left(t \cdot h a^{-1}\right)$ & & & & & \\
\hline L1 & $75.89^{a}$ & $2.28^{c}$ & $43.35^{b}$ & $34.81^{b}$ & $17.95^{b}$ & $3.17^{\mathrm{b}}$ & $5.37^{a}$ & $10.27^{b}$ & $17,285.83^{b}$ & $14.01^{b}$ \\
\hline L2 & $73.33^{a}$ & $2.38^{b}$ & $48.44^{\mathrm{a}}$ & $39.34^{\mathrm{a}}$ & $20.69^{a b}$ & $3.66^{\mathrm{a}}$ & $5.43^{a}$ & $12.18^{a b}$ & $19,534.96^{\mathrm{ab}}$ & $14.62^{a b}$ \\
\hline L3 & $73.00^{\mathrm{a}}$ & $2.45^{\mathrm{a}}$ & $51.66^{\mathrm{a}}$ & $42.70^{\mathrm{a}}$ & $21.89^{a}$ & $3.93^{a}$ & $5.03^{a}$ & $14.76^{\mathrm{a}}$ & $20,783.12^{a}$ & $16.04^{\mathrm{a}}$ \\
\hline $\mathrm{F} 1$ & $72.78^{a}$ & $2.39^{\mathrm{a}}$ & $50.77^{a}$ & $41.05^{\mathrm{a}}$ & $22.57^{\mathrm{a}}$ & $3.86^{\mathrm{a}}$ & $5.86^{\mathrm{a}}$ & $13.53^{a}$ & $22,529.59^{\text {a }}$ & $15.01^{\mathrm{a}}$ \\
\hline $\mathrm{F} 2$ & $73.56^{a}$ & $2.38^{a b}$ & $47.53^{a b}$ & $38.54^{\mathrm{ab}}$ & $20.16^{a b}$ & $3.59^{a b}$ & $5.40^{a b}$ & $12.67^{\mathrm{a}}$ & $18,722.60^{\mathrm{b}}$ & $15.29^{\mathrm{a}}$ \\
\hline F3 & $75.89^{a}$ & $2.33^{b}$ & $45.14^{b}$ & $37.26^{b}$ & $17.80^{b}$ & $3.32^{b}$ & $4.57^{\mathrm{b}}$ & $11.01^{\mathrm{a}}$ & $16,351.71^{\mathrm{b}}$ & $14.37^{\mathrm{a}}$ \\
\hline
\end{tabular}

$\mathrm{Tx}=$ treatment. Different literals in the same column indicate significant differences. 
Regarding production parameters for juice, JW, JV, and ${ }^{\circ} \mathrm{B}$ showed similarity with reported values from other varieties: values for JW ranged from 16.43 (Ramada) to 28.10 t.ha ${ }^{-1}$ (Mn-4508);

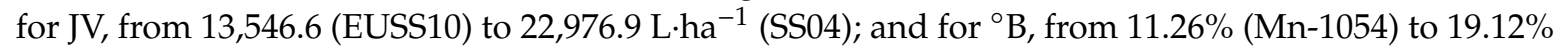
(SS-301) [41,45]. These parameters vary by genetic, climatic, and edaphic factors [46]. Although none of the fertilization treatments included nitrogen levels of $80-120 \mathrm{~kg} \cdot \mathrm{N} \cdot \mathrm{ha}^{-1}$ (recommended) for sweet sorghum [47,48], ROGER showed similar agronomic yields. This can be explained by the genotypic characteristics of the variety, which allows adaptation to limited nutrient environments [22].

\subsection{Energy Balance}

\subsubsection{Energy in Mechanized Agricultural Labor}

Table 4 shows the energy expenditure in mechanized agricultural labor for sweet sorghum production. The most energy demanding labor was F2 (9080.97 MJ.ha $\left.{ }^{-1}\right)$, higher than F1, which was almost three times as energy efficient (3426.65 MJ.ha ${ }^{-1}$ ) as inorganic. However, this result was lower than the 15,801 MJ.ha ${ }^{-1}$ reported by Ren et al. [33] in another sweet sorghum variety. Such behavior could be the result of lower fertilization dose, specifically nitrogen. Thus, our results confirm that mineral (inorganic) fertilizers, among different sources of energy, are the greatest contributors to energy consumption $[49,50]$. This is particularly evident with nitrogen fertilizers.

Within the energy requirements in all the work carried out, the main source of energy for its execution was diesel fuel, which coincided with other research [49]. Subsoil labor had the maximum energy expenditure (1696.9 MJ.ha ${ }^{-1}$ ). This number reflects the depth of labor, equipment size, speed of work, conditions, and type of soil due to the degree of compaction [51]. The traction of agricultural equipment depends on the mechanical resistance of the soil to penetration, which in turn, is influenced by the depth of labor and the tool-ground contact area of the equipment. For tool-ground contact area, the geometry of the cutting tool (angle of attack) is decisive [52]. Thus, a reduction in energy costs for high-fuel-consumption labor (subsoil and plow) could be achieved by employing multiplows that reduce labor activities [51]. Conversely, lower-energy labor corresponds to superficial soil labor [24], such as the clearing labor in this study.

Table 4. Energy expenditure of mechanized agricultural labor in sweet sorghum.

\begin{tabular}{|c|c|c|c|c|c|c|c|}
\hline \multirow{2}{*}{ Labor } & ESM & $\mathrm{ESF}^{+}$ & ESL & ESR & ESH & ESI & Total \\
\hline & \multicolumn{7}{|c|}{ MJ.ha ${ }^{-1}$} \\
\hline Clearing * & 27.94 & $406.3^{£}$ & 23.94 & 36.04 & 0.63 & - & 494.55 \\
\hline Plowing & 113.69 & 1386.2 & 112.22 & 146.67 & 1.46 & - & 1760.24 \\
\hline Subsoil & 192.96 & $1696.9^{\bar{\top}}$ & 194.09 & 248.91 & 2.23 & - & 2335.09 \\
\hline Dredge & 93.07 & 1080.28 & 63.86 & 120.06 & 0.90 & - & 1358.17 \\
\hline Crossing & 89.99 & 970.34 & 57.15 & 116.09 & 0.87 & - & 1234.44 \\
\hline Recrossing & 83.12 & 979.9 & 57.79 & 107.23 & 0.80 & - & 1228.84 \\
\hline Sowing & 115.24 & 812.6 & 47.84 & 148.66 & 9.69 & $417.20^{¥}$ & 1551.23 \\
\hline Organic fertilization & 58.55 & 554.48 & 32.85 & 75.52 & 5.25 & $2700 \S$ & 3426.65 \\
\hline Inorganic fertilization ^ & 58.55 & 573.6 & 33.88 & 37.55 & 5.39 & $8372 \mathbb{I}$ & 9080.97 \\
\hline Weeding & 38.65 & 836.5 & 49.16 & 49.86 & 0.96 & - & 925.97 \\
\hline Cultivation and hilling & 25.73 & 573.6 & 33.73 & 33.20 & 0.63 & - & 666.89 \\
\hline Weed control & 50.99 & 454.1 & 26.61 & 65.78 & 7.06 & $3211^{c}$ & 925.54 \\
\hline Pest control & 53.72 & 430.2 & 25.31 & 69.30 & 2.21 & $417^{\ominus}$ & 997.74 \\
\hline Irrigation & 139.56 & $1601.3^{\&}$ & 110.08 & 180 & 7.84 & $214.87^{\#}$ & 2253.65 \\
\hline Harvest, transport, and grinding & 179.5 & 1625.2 & 137.95 & 231.55 & 24.85 & - & 2199.05 \\
\hline
\end{tabular}

+ Main source of energy; ^ Labor with the highest energy requirement; " Labor with the lowest energy requirement;

${ }^{\bar{T}}$ Higher energy input by fuel; ${ }^{£}$ Lower energy input by fuel; ${ }^{¥}$ Energy used in seed; $§$ Energy used in poultry manure;

II Energy used in inorganic fertilizer; ${ }^{\mathbf{C}}$ Energy used in herbicides; ${ }^{\ominus}$ Energy used in insecticides; and \& Electricity;

\# Irrigation water. 


\subsubsection{Energy Indexes}

Energy indexes in the production systems showed significant differences $(p \leq 0.05)$ and highly significant differences $(p<0.01)$, without interaction between tillage and fertilization treatments (Table 5).

Table 5. Analysis of variance for energy indexes.

\begin{tabular}{cccccccc}
\hline \multirow{2}{*}{ S.V. } & D.F. & \multicolumn{7}{c}{ MS } \\
\cline { 3 - 7 } & & IE $^{\mathbf{1}}$ & $\mathbf{O E}^{\mathbf{2}}$ & EE $^{\mathbf{3}}$ & $\mathbf{E P}^{\mathbf{4}}$ & $\mathbf{S E}^{\mathbf{5}}$ & $\mathbf{N E}^{\mathbf{6}}$ \\
\hline Repetition & 2 & $7.27 \times 10^{6}$ & $1.75 \times 10^{9}$ & 0.12 & 0.03 & 0.03 & $1.53 \times 10^{9}$ \\
Tillage & 2 & $1.27 \times 10^{8 * *}$ & $4.73 \times 10^{9 *}$ & $15.67^{* *}$ & $0.28^{*}$ & $0.25^{* *}$ & $3.41 \times 10^{9 *}$ \\
Error (a) & 4 & $2.96 \times 10^{6}$ & $6.79 \times 10^{8}$ & 0.19 & 0.03 & 0.05 & $5.97 \times 10^{8}$ \\
Fertilization & 2 & $1.81 \times 10^{8 * *}$ & $5.6 \times 10^{9 *}$ & $44.89^{* *}$ & $0.89^{* *}$ & $0.10^{\mathrm{ns}}$ & $5.08 \times 10^{9}$ \\
Tillage $\times$ Fertilization & 4 & $2.01 \times 10^{5} \mathrm{~ns}$ & $3.79 \times 10^{8 \mathrm{~ns}}$ & $2.04^{\mathrm{ns}}$ & $0.03^{\mathrm{ns}}$ & $0.04^{\mathrm{ns}}$ & $3.88 \times 10^{8} \mathrm{~ns}$ \\
Error (b) & 12 & $3.71 \times 10^{6}$ & $1.01 \times 10^{9}$ & 0.13 & 0.05 & 0.03 & $8.96 \times 10^{8}$ \\
C.V. (\%) & & 7.68 & 9.17 & 2.55 & 11.49 & 2.51 & 9.30 \\
\hline
\end{tabular}

${ }^{1}$ Energy input; ${ }^{2}$ Energy output; ${ }^{3}$ Energy relationship; ${ }^{4}$ Energy productivity; ${ }^{5}$ Specific energy; ${ }^{6}$ Net energy;

* Significant at $0.05 ; *$ Significant at 0.01 ; ${ }^{\text {ns }}$ : not significant at 0.05 .

Table 6 shows the comparison of means for energy indexes for each production system.

Table 6. Energy indexes in production systems.

\begin{tabular}{|c|c|c|c|c|c|c|}
\hline \multirow{2}{*}{$\mathbf{T x}$} & IE $^{1}$ & $\mathrm{OE}^{2}$ & \multicolumn{4}{|c|}{ Index } \\
\hline & \multicolumn{2}{|c|}{ MJ.ha-1 } & $\mathrm{EE}^{3}$ & $\mathrm{EP}^{4}\left(\mathrm{~kg} \cdot \mathrm{MJ}^{-1}\right)$ & $\mathrm{SE}^{5}\left(\mathrm{MJ} \cdot \mathrm{kg}^{-1}\right)$ & $\mathrm{NE}^{6}\left(\mathrm{MJ} \cdot \mathrm{ha}^{-1}\right)$ \\
\hline L1 & $21,278.95^{c}$ & $321,525.07^{b}$ & $15.11^{a}$ & $2.04^{\mathrm{a}}$ & $7.42^{a}$ & $300,246.12^{b}$ \\
\hline L2 & $23,549.98^{b}$ & $352,301.98^{a b}$ & $14.96^{\mathrm{a}}$ & $2.05^{\mathrm{a}}$ & $7.27^{a b}$ & $328,752 \mathrm{ab}$ \\
\hline L3 & $26,093.27^{\mathrm{a}}$ & $366,349.52^{a}$ & $14.04^{b}$ & $1.98^{b}$ & $7.08^{b}$ & $340,256.25^{a}$ \\
\hline $\mathrm{F} 1$ & $20,434.93^{b}$ & $371,806.87^{a}$ & $18.19^{a}$ & $2.48^{\mathrm{a}}$ & $7.33^{a}$ & $351,371.94^{a}$ \\
\hline $\mathrm{F} 2$ & $26,225.35^{a}$ & $346,436.95^{a b}$ & $13.21^{b}$ & $1.81^{b}$ & $7.30^{\mathrm{a}}$ & $320,211.64^{a b}$ \\
\hline F3 & $17,234.09^{c}$ & $321,932.76^{b}$ & $18.68^{a}$ & $2.62^{a}$ & $7.13^{a}$ & $304,698.67^{b}$ \\
\hline
\end{tabular}

$\mathrm{Tx}=$ treatment; $\mathrm{L}=$ tillage treatment; $\mathrm{F}=$ fertility treatment; ${ }^{1}$ Energy input; ${ }^{2}$ Energy output; ${ }^{3}$ Energy efficiency;

${ }^{4}$ Energy productivity; ${ }^{5}$ Specific energy; ${ }^{6}$ Net energy; and ${ }^{a-c}$ Different letters in the same column denote statistically significant differences.

It is observed that the L1 (21,278.95 MJ.ha $\left.{ }^{-1}\right)$ and F3 $\left(17,234.09 \mathrm{MJ} \cdot \mathrm{ha}^{-1}\right)$ production systems had the lowest IE per hectare. Energy input was less than the 27,089 MJ.ha ${ }^{-1}$ mentioned by Ren et al. [33], but it was greater than the $18,399 \mathrm{MJ} \cdot \mathrm{ha}^{-1}$ reported by Dar et al. [53]. This behavior could be the result of fuel expense derived from the number of tasks or inputs used (fertilizers, herbicides, insecticides, etc.). On the other hand, the highest OE was for L3 (366,349.52 MJ.ha ${ }^{-1}$ ) and F1 (371,806.87 MJ.ha $\left.{ }^{-1}\right)$. These values are in the range of 250,000-422,000 MJ.ha ${ }^{-1}$ [54], and they depend on the agronomic performance and calorific value of the plant material. The highest numerical value of EE was for L1 (15.11) and F3 (18.68). These values were in the range of 10-32, as mentioned by Venturi and Venturi [54], and surpassed the value of 12.4 described by Ren et al. [33]. Our results could be a product of efficient management and conditions in production systems, particularly due to effective operation of agricultural machinery [55]. EP is directly related to agronomic performance of the crop and the energy investment in the production process. L2 $\left(2.05 \mathrm{~kg} \cdot \mathrm{MJ}^{-1}\right)$ and F3 $\left(2.62 \mathrm{~kg} \cdot \mathrm{MJ}^{-1}\right)$ showed the highest values; these results were higher than those reported by Monti and Venturi [49] of $0.7 \mathrm{~kg} \cdot \mathrm{MJ}^{-1}$.

In the case of SE, the highest numerical value was observed in L1 $\left(7.42 \mathrm{MJ} \cdot \mathrm{kg}^{-1}\right)$. However, the highest values of NE were shown in L3 $\left(340,256.25 \mathrm{MJ} \cdot \mathrm{ha}^{-1}\right)$ and F1 $\left(351,371.94 \mathrm{MJ} \cdot \mathrm{ha}^{-1}\right)$, but they were statistically equal to L3 and F2, respectively. These values surpassed other production systems with values of 121,500 [50] and 223,928 MJ.ha ${ }^{-1}$ [53]. Our results show the energy potential of this sorghum 
variety under the production systems tested, where energy indexes depended on the agronomic performance of the crop, consumption of fuel and fertilizers, and agronomic conditions of production.

\section{Conclusions}

The agronomic parameters of the new ROGER variety were evaluated. This variety produced considerable yields of biomass and juice despite cultivation in a semiarid zone. Likewise, the results of the energy balance indicated high energy efficiency under the different production systems tested. Both desirable characteristics show the potential that the ROGER variety has for the production of bioethanol. This potential will be evaluated in future research to obtain first- and second-generation bioethanol.

Author Contributions: Conceptualization: F.Z.G. and I.L.S.; Methodology: F.Z.G., G.G.S., A.G.D., E.G.C. and N.M.H.; Software: F.Z.G. and I.L.S.; Validation: F.Z.G., I.L.S., G.G.S., A.G.D., N.M.H. and E.G.C.; Formal analysis: F.Z.G., I.L.S. and G.G.S.; Research: F.Z.G., I.L.S. and G.G.S.; Resources: F.Z.G. and G.G.S.; Data curation: F.Z.G., I.L.S. and G.G.S.; Writing — preparation of the original draft: I.L.S., F.Z.G. and G.G.S.; Writing—revision and editing: F.Z.G., I.L.S. and G.G.S.; Visualization: F.Z.G. and I.L.S.; Supervision: F.Z.G. and G.G.S.; Project management: F.Z.G. and G.G.S.; Acquisition of funds: F.Z.G. and G.G.S.

Funding: This research was partially funded by the Autonomous University of Nuevo León, specifically, the Faculty of Agronomy. Direct funding was also received from the SWEETFUEL project (Sweet sorghum: an alternative energy crop; 227422) financed by the European Community.

Acknowledgments: To the Autonomous University of Nuevo León for the support of this research and to the National Council of Science and Technology (Conacyt) Scholarship for Doctoral Studies in Agricultural Sciences.

Conflicts of Interest: The authors declare no conflict of interest.

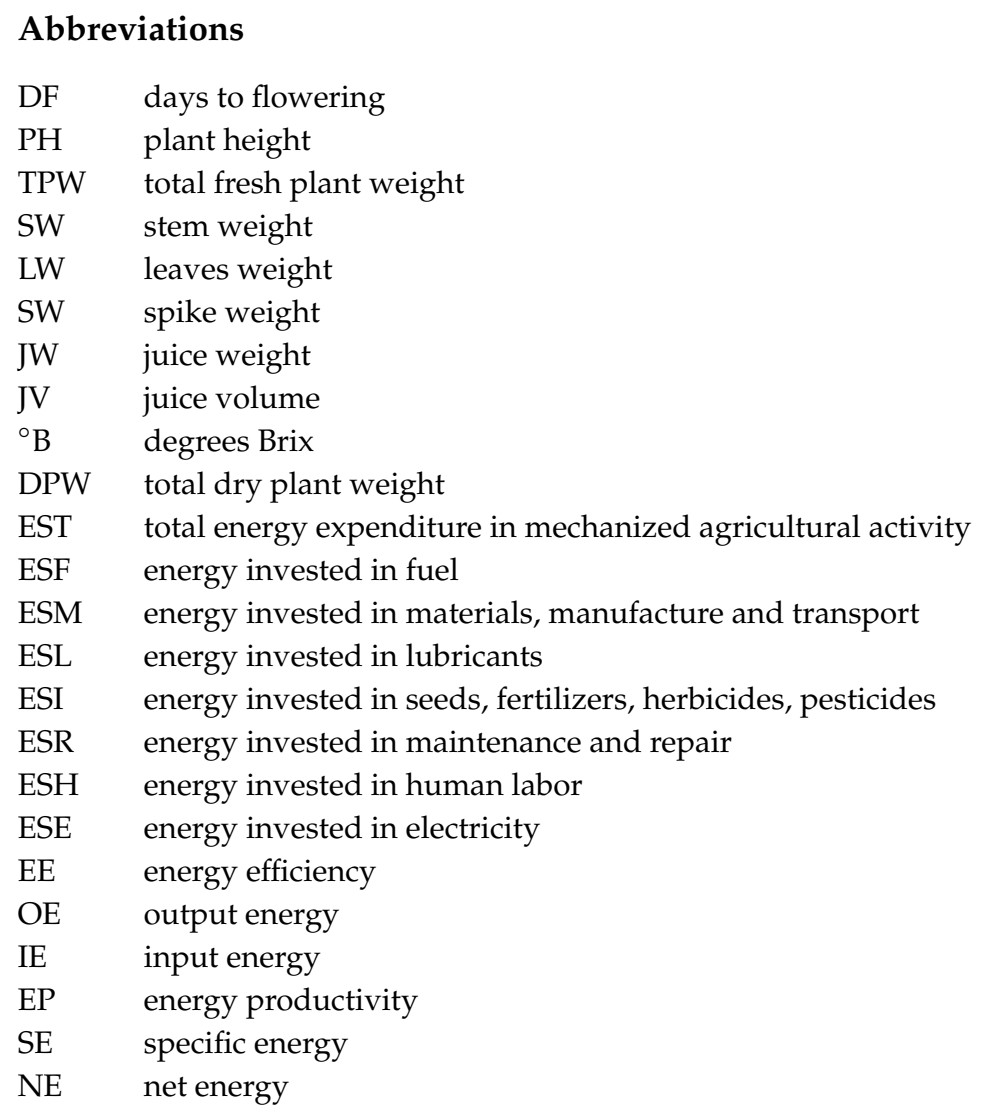




\section{References}

1. Su, Y.; Zhang, P.; Su, Y. An overview of biofuels policies and industrialization in the major biofuel producing countries. Renew. Sustain. Energy Rev. 2015, 50, 991-1003. [CrossRef]

2. Rocha, A.; Araújo, A.; Carvalho, A.; Sepulveda, J.A. New Approach for Real Time Train Energy Efficiency Optimization. Energies 2018, 11, 2660. [CrossRef]

3. Haciseferogullari, H.; Acaroglu, M.; Gezer, I. Determination of the energy balance of the sugar beet plant. Energy Source 2003, 25, 15-22. [CrossRef]

4. Pervanchon, F.; Bockstaller, C.; Girardin, P. Assessment of energy use in arable farming systems by means of an agro-ecological indicator: the energy indicator. Agric. Syst. 2002, 72, 149-172. [CrossRef]

5. Wiśnicki, B.; Chybowski, L.; Czarnecki, M. Analysis of the efficiency of port container terminals with the use of the Data Envelopment Analysis method of relative productivity evaluation. Manag. Syst. Prod. Eng. 2017, 25, 9-15. [CrossRef]

6. Rathke, G.W.; Wienhold, B.J.; Wilhelm, W.W.; Diepenbrock, W. Tillage and rotation effect on corn-soybean energy balances in eastern Nebraska. Soil Till Res. 2007, 97, 60-70. [CrossRef]

7. Esengun, K.; Erdal, G.; Gündüz, O.; Erdal, H. An economic analysis and energy use in stake-tomato production in Tokat province of Turkey. Renew. Energy 2007, 32, 1873-1881. [CrossRef]

8. Wang, M.; Chen, Y.; Xia, X.; Li, J.; Liu, J. Energy efficiency and environmental performance of bioethanol production from sweet sorghum stem based on life cycle analysis. Bioresour. Technol. 2014, 163, 74-81. [CrossRef] [PubMed]

9. Larnaudie, V.; Rochon, E.; Ferrari, M.D.; Lareo, C. Energy evaluation of fuel bioethanol production from sweet sorghum using very high gravity (VHG) conditions. Renew. Energy 2016, 88, 280-287. [CrossRef]

10. Mathur, S.; Umakanth, A.V.; Tonapi, V.A.; Sharma, R.; Sharma, M.K. Sweet sorghum as biofuel feedstock: recent advances and available resources. Biotechnol. Biofuels 2017, 10, 146. [CrossRef]

11. Bai, Y.; Luo, L.; van der Voet, E. Life cycle assessment of switchgrass-derived ethanol as transport fuel. Int. J. Life Cycle Assess. 2010, 15, 468-477. [CrossRef]

12. Vermerris, W.; Saballos, A. Genetic enhancement of sorghum for biomass utilization. In Genomics of the Saccharinae; Paterson, A., Ed.; Springer: New York, NY, USA, 2013; Volume 11, pp. 391-425, ISBN 978-1-4419-5947-8.

13. Cifuentes, R.; Bressani, R.; Rolz, C. The potential of sweet sorghum as a source of ethanol and protein. Energy Sustain. Dev. 2014, 21, 13-19. [CrossRef]

14. Regassa, T.H.; Wortmann, C.S. Sweet sorghum as a bioenergy crop: literature review. Biomass Bioenergy 2014, 64, 348-355. [CrossRef]

15. Mishra, J.S.; Kumar, R.; Rao, S.S. Performance of sweet sorghum (Sorghum bicolor) cultivars as a source of green fodder under varying levels of nitrogen in semi-arid tropical India. Sugar Tech. 2017, 19, 532-538. [CrossRef]

16. Cosedido, V.; Vacas, R.; Macarulla, B.; Gracia, M.P.; Igartua, E. Agronomic and digital phenotyping evaluation of sweet sorghum public varieties and F1 hybrids with potential for ethanol production in Spain. Maydica 2013, 58, 42-53.

17. Barcelos, C.A.; Maeda, R.N.; Santa Anna, L.M.; Pereira, N. Sweet sorghum as a whole-crop feedstock for ethanol production. Biomass Bioenergy 2016, 94, 46-56. [CrossRef]

18. Bonin, C.L.; Heaton, E.A.; Cogdill, T.J.; Moore, K.J. Management of sweet sorghum for biomass production. Sugar Tech. 2016, 18, 150-159. [CrossRef]

19. Tsuchihashi, N.; Goto, Y. Cultivation of sweet sorghum (Sorghum bicolor (L.) Moench) and determination of its harvest time to make use as the raw material for fermentation, practiced during rainy season in dry land of Indonesia. Plant Prod. Sci. 2004, 7, 442-448. [CrossRef]

20. Pabendon, M.B.; Efendi, R.; Santoso, S.B.; Prastowo, B. Varieties of sweet sorghum Super-1 and Super-2 and its equipment for bioethanol in Indonesia. IOP Conf. Ser. Earth Environ. Sci. 2017, 65. [CrossRef]

21. Vanderlip, R.L. How a Sorghum Plant Develop. Available online: https://www.bookstore.ksre.ksu.edu/pubs/ s3.pdf (accessed on 6 May 2019).

22. Davila, F.J.; Chuck, C.; Perez, E.; Rooney, W.L.; Serna, S.O. Evaluation of bioethanol production from five different varieties of sweet and forage sorghums (Sorghum bicolor (L) Moench). Ind. Crops Prod. 2011, 33, 611-616. [CrossRef] 
23. de las Cuevas Milán, H.R.; Rodríguez Hernández, T.; Paneque Rondón, P.; Díaz Álvarez, M. Costo energético del rodillo de cuchillas CEMA 1400 para cobertura vegetal. Revista Ciencias Técnicas Agropecuarias 2011, 20, 53-56.

24. Paneque, P.; Sánchez, Y. Costo energético de la cosecha mecanizada del arroz en Cuba. Revista Ciencias Técnicas Agropecuarias 2006, 15, 18-22.

25. Bridges, T.C.; Smith, E.M. A method for determining the total energy input for agricultural practices. Trans. ASAE 1979, 22, 781-0784. [CrossRef]

26. Stout, B.A. Handbook of Energy for World Agriculture, 1st ed.; Texas A \& M University: College Station, TX, USA, 1990; pp. 50-95, ISBN 1-85166-349-5.

27. Tabatabaeefar, A.; Emamzadeh, H.; Varnamkhasti, M.G.; Rahimizadeh, R.; Karimi, M. Comparison of energy of tillage systems in wheat production. Energy 2009, 34, 41-45. [CrossRef]

28. Singh, S.; Mittal, J.P. Energy in Production Agriculture, 1st ed.; Mittal Publications: New Delhi, India, 1992; ISBN 81-7099-407-1.

29. Kitani, O.; Jungbluth, T. Energy and biomass engineering. In CIGR-The International Commission of Agricultural Engineering; Kitani, O., Jungbluth, T., Peart, R.M., Ramdani, A., Eds.; American Society of Agricultural Engineers: St Joseph, MI, USA, 1999; Volume 5, p. 17, ISBN 0-929355-97-0.

30. Vilche, M.S.; Denoia, J.; Montico, S.; Tonel, B.; Dileo, N. El uso de la energía en los sistemas agropecuarios del distrito Zavalla (Santa FE). RevIsta Científica Agropecuaria 2006, 10, 7-19.

31. Yilmaz, I.; Akcaoz, H.; Ozkan, B. An analysis of energy use and input costs for cotton production in Turkey. Renew. Energy 2005, 30, 145-155. [CrossRef]

32. Meul, M.; Nevens, F.; Reheul, D.; Hofman, G. Energy use efficiency of specialised dairy, arable and pig farms in Flanders. Agric. Ecosyst. Environ. 2007, 119, 135-144. [CrossRef]

33. Ren, L.T.; Liu, Z.X.; Wei, T.Y.; Xie, G.H. Evaluation of energy input and output of sweet sorghum grown as a bioenergy crop on coastal saline-alkali land. Energy 2012, 47, 166-173. [CrossRef]

34. Mohammadi, A.; Tabatabaeefar, A.; Shahin, S.; Rafiee, S.; Keyhani, A. Energy use and economical analysis of potato production in Iran a case study: Ardabil province. Energy Convers. Manag. 2008, 49, 3566-3570. [CrossRef]

35. Hatirli, S.A.; Ozkan, B.; Fert, C. An econometric analysis of energy input-output in Turkish agriculture. Renew. Sustain. Energy Rev. 2005, 9, 608-623. [CrossRef]

36. Fluck, R.C. Energy sequestered in repairs and maintenance of agricultural machinery. Trans. ASAE 1985, 28, 738-744. [CrossRef]

37. Paneque, P.; Fernández, H.C.; de Oliveira, A.D. Comparación de cuatro sistemas de labranza/siembra en relación con su costo energético. Revista Ciencias Técnicas Agropecuarias 2002, 11, 1-6.

38. Tabatabaie, S.M.H.; Rafiee, S.; Keyhani, A.; Ebrahimi, A. Energy and economic assessment of prune production in Tehran province of Iran. J. Clean Prod. 2013, 39, 280-284. [CrossRef]

39. Nabavi, A.; Rafiee, S.; Hosseinzadeh, H.; Shamshirband, S. Modeling energy consumption and greenhouse gas emissions for kiwifruit production using artificial neural networks. J. Clean Prod. 2016, 133, 924-931. [CrossRef]

40. Furlani, C.E.A.; Bertonha, R.S.; Vicente Filho, A.S.; Compagnon, A.M.; Cassia, M.T. Energy demand of furrow openers and corn yield according to the soil disturbance in no till system. Afr. J. Agric. Res. 2016, 11, 1538-1542.

41. Oyier, M.O.; Owuoche, J.O.; Oyoo, M.E.; Cheruiyot, E.; Mulianga, B.; Rono, J. Effect of harvesting stage on sweet sorghum (Sorghum bicolor L.) genotypes in western Kenya. Sci. World J. 2017, 2017. [CrossRef] [PubMed]

42. Disasa, T.; Feyissa, T.; Admassu, B. Characterization of Ethiopian sweet sorghum accessions for Brix, morphological and grain yield traits. Sugar Tech. 2017, 19, 72-82. [CrossRef]

43. Reddy, B.V.; Ashok Kumar, A.; Ravinder Reddy, C.; Rao, P.P.; Patil, J.V. Developing a Sweet Sorghum Ethanol Value Chain; International Crops Research Institute for the Semi-Arid Tropics: Patancheru, India, 2013. Available online: http://oar.icrisat.org/id/eprint/6769 (accessed on 17 September 2017).

44. Pothisoong, T.; Jaisil, P. Yield potential, heterosis and ethanol production in F1 hybrids of sweet sorghum (Sorghum bicolor L. Moench). CAST 2011, 11, 17-24.

45. Khalil, S.R.; Abdelhafez, A.A.; Amer, E.A.M. Evaluation of bioethanol production from juice and bagasse of some sweet sorghum varieties. AOAS 2015, 60,317-324. [CrossRef] 
46. Amaducci, S.; Monti, A.; Venturi, G. Non-structural carbohydrates and fibre components in sweet and fibre sorghum as affected by low and normal input techniques. Ind. Crops Prod. 2004, 20, 111-118. [CrossRef]

47. Sawargaonkar, G.L.; Wani, S.P. Nitrogen response of sweet sorghum genotypes during rainy season. Curr. Sci. 2016, 110, 1699-1703.

48. Almodares, A.; Taheri, R.; Chung, M.; Fathi, M. The effect of nitrogen and potassium fertilizers on growth parameters and carbohydrate contents of sweet sorghum cultivars. J. Environ. Biol. 2008, 29, 849-852.

49. Monti, A.; Venturi, G. Comparison of the energy performance of fibre sorghum, sweet sorghum and wheat monocultures in northern Italy. Eur. J. Agron. 2003, 19, 35-43. [CrossRef]

50. Ding, N.; Yang, Y.; Cai, H.; Liu, J.; Ren, L.; Yang, J.; Xie, G.H. Life cycle assessment of fuel ethanol produced from soluble sugar in sweet sorghum stalks in North China. J. Clean. Prod. 2017, 161, 335-344. [CrossRef]

51. Rondón, P.P.; León, D.S. Costo energético de las labores de preparación de suelo en Cuba. Revista Ciencias Técnicas Agropecuarias 2007, 16, 17-21.

52. Palma, A.Z.; Volpato, E.S.; Barbosa, J.A.; Spagnolo, R.T.; Barros, M.D.; Boas, V.; do Amaral, L. Effects of work operation depth of shanks in a seeder-fertilizer on slip, traction force and fuel consumption of a tractor. Ciênc. Agrotec. 2010, 34, 1320-1326. [CrossRef]

53. Dar, R.A.; Dar, E.A.; Kaur, A.; Phutela, U.G. Sweet sorghum-a promising alternative feedstock for biofuel production. Renew. Sustain. Energy Rev. 2017, 82. [CrossRef]

54. Venturi, P.; Venturi, G. Analysis of energy comparison for crops in European agricultural systems. Biomass Bioenergy 2003, 25, 235-255. [CrossRef]

55. Dyjakon, A. The Influence of the Use of Windrowers in Baler Machinery on the Energy Balance during Pruned Biomass Harvesting in the Apple Orchard. Energies 2018, 11, 3236. [CrossRef]

(C) 2019 by the authors. Licensee MDPI, Basel, Switzerland. This article is an open access article distributed under the terms and conditions of the Creative Commons Attribution (CC BY) license (http://creativecommons.org/licenses/by/4.0/). 